\title{
AGREEABLENESS SEBAGAI MODERATOR HUBUNGAN EKSPOSUR TAYANGAN ANTISOSIAL DAN PERUNDUNGAN-SIBER PADA REMAJA
}

\author{
Nisa Fitriani \\ IAIN Tulungagung \\ nisafitriani1991@gmail.com
}

\begin{abstract}
This study examined the moderating effect of agreeableness on the relation between exposure of antisocial media and cyberbullying. The subjects of the research were 293 junior high school students 12-16 years old $(M=13,58 ; S D=0,74)$ in Malang City. Instruments used were The Cyberbullying Questionnaire, Content-based Media Exposure Scale, and The Big Five Inventory. The result indicated that agreeableness is moderator exposure of antisocial media and cyberbullying $(\beta=-0,155$; $p=0,006)$. Correlation between exposure of antisocial media and cyberbullying is stronger in adolescents with low levels of agreeableness than adolescents with high agreeableness.
\end{abstract}

Keywords: agreeableness, cyberbullying, exposure of antisocial media

\begin{abstract}
ABSTRAK
Pada penelitian ini berusaha untuk menguji efek moderasi pada agreeableness terhadap hubungan antara eksposur tayangan antisosial dan perundungan-siber. Subjek penelitian adalah 293 siswa SMP di Kota Malang usia 12-16 tahun $(M=13,58 ; S D=0,74)$. Instrumen yang digunakan adalah The Cyberbullying Questionnaire, Content-based Media Exposure Scale, dan The Big Five Inventory. Hasil penelitian memutuskan agreeableness adalah moderator hubungan eksposur tayangan antisosial dan perundungan-siber $(\beta=-0,155 ; p=0,006)$. Hubungan eksposur tayangan antisosial dan perundungan-siber lebih kuat pada remaja dengan level agreeableness rendah dibandingkan remaja dengan agreeableness tinggi.
\end{abstract}

Kata kunci: agreeableness, eksposur tayangan antisosial, perundungan-siber 


\section{PENDAHULUAN}

Pada tahun 2020 Indonesia memiliki pengguna internet sebanyak 272, 1 juta dengan persentase 55\% (we are social, 2020). Tingginya angka tersebut dikhawatirkan diiringi oleh munculnya penyalahgunaan, yaitu melakukan perundungan-siber (cyberbullying). Survei global yang diprakarsai oleh lembaga riset Ipsos pada tahun 2012 mengungkapkan bahwa Indonesia merupakan negara dengan kasus perundungan-siber tertinggi kedua setelah India. Adapun dampak dari perundungan-siber berdasarkan studi meta analisis adalah peningkatan depresi, kecemasan, kesepian serta mengalami penurunan pada kepuasan hidup, harga diri, prestasi akademik, hingga munculnya keinginan bunuh diri (Kowalski, Giumetti, Schroeder, \& Lattanner, 2014).

Dengan adanya prevalensi dan dampak, tentu penting untuk mengeksplorasi variabel yang berkontribusi pada peningkatan kecenderungan perundungan-siber. Salah satu variabel yang telah banyak ditemukan memiliki korelasi dengan perundungan-siber adalah eksposur tayangan antisosial (Den Hamer dan Konijin, 2015). Walaupun demikian, peneliti lainnya (Ferguson dan Wang, 2019) menyatakan bahwa seseorang yang menonton tayangan berkonten antisosial belum tentu mewujudkannya di dunia nyata. Mengingat tidak adanya konsensus, maka diduga terdapat moderator (agreeableness) yang mempengaruhi hubungan eksposur tayangan antisosial dan perundungan-siber.

Subjek penelitian ini adalah remaja. Rasionalnya adalah karena hasil riset baik dari Indonesia maupun luar dengan metode yang berbeda menunjukkan bahwa remaja usia 12-14 tahun atau kelas 7 dan kelas 8 paling rentan terlibat perundungan-siber (Tokunaga,2010; Kowalski et al., 2014; Mawardah \& Adiyanti, 2014). Dengan demikian tujuan penelitian ini adalah untuk mengetahui peran agreeableness sebagai moderator hubungan eksposur tayangan antisosial dan perundungan-siber. Diharapkan hasil penelitian ini memberi mafaat secara teoris dan praktis pada bidang psikologi sosial 
dan secara khusus untuk mengurangi efek dari eksposur tayangan antisosial terhadap cyberbullying melalui usaha peningkatan agreeableness.

Perundungan adalah tipe spesifik dari agresi yang bertujuan untuk mengganggu pihak lain yang lebih lemah secara berulang-ulang oleh kelompok atau individu yang lebih kuat (Nansel, Overpeck, Haynie, Ruan, \& Scheidt, 2003). Dari pengertian tersebut diketahui bahwa komponen perundungan adalah agresi, pengulangan perilaku, dan ketidakseimbangan kekuatan. Oleh karena perundungansiber merupakan bagian dari perundungan itu sendiri maka keduanya memiliki komponen yang sama. Adapun perbedaan nya yaitu pada manifestasi komponennya, terutama "pengulangan perilaku" dan "ketidakseimbangan kekuatan”. Pengulangan perilaku digambarkan di dalam perundungan sebagai agresi yang secara berulang dilakukan oleh individu atau kelompok kepada seorang korban. Smith (2015) berpendapat, ketika berada dalam domain virtual, perilaku tunggal menjadi viral dan diteruskan oleh orang lain, dan hal ini seringkali diperkirakan oleh pelaku. Jadi, yang dimaksud dengan pengulangan perilaku di dalam perundungan-siber adalah perilaku tunggal (seperti mengirim gambar vulgar), namun berlangsung secara terus-menerus karena dilanjutkan oleh orang lain.

Kriteria kedua ketidakseimbanagan kekuatan. Apabila ketidakseimbangan kekuatan di dalam perundungan biasanya dipengaruhi oleh kekuatan fisik, popularitas, dan status sosial maka untuk perundungan-siber adalah anonimitas, efisiensi, dan besarnya audiens (Dordolo, 2014). Dengan demikian definisi perundungan-siber adalah agresi yang dilakukan oleh individu atau kelompok kepada korban yang tidak memiliki kekuatan untuk mempertahankan diri melalui media online.

Willard (2007) membagi perundungan-siber menjadi enam, yaitu flamming, harassment, denigration, impersonation, outing, trickery, exclusion, dan cyberstalking. Flamming, adalah penggunaan pesan elektronik dengan bahasa permusuhan dan vulgar. Harassment adalah mengirim 
pesan ancaman dan menakutkan. Denigration adalah mengirim atau mem-posting gosip atau rumor tentang seseorang untuk menghancurkan reputasi atau hubungan persahabatannya. Impersonation adalah menyalahgunakan akun seseorang dengan cara berpura-pura menjadi pemilik akun lalu mengirim atau mem-posting materi yang membuat pemilik akun memperoleh masalah atau menghacurkan reputasi pemilik akun. Outing adalah membagikan informasi atau gambar/video yang rahasia atau memalukan milik orang lain secara online. Trickery adalah berkomunikasi dengan seseorang untuk menemukan rahasia atau informasi memalukan untuk dibagikan secara online. Exclusion adalah secara sadar dan kejam mengeluarkan seseorang dari grup online. Cyberstalking adalah menciptakan rasa takut dengan melakukan fitnah dan kekerasan secara intens dan berulang. Sementara menurut Calvete et al. (2010) perundungan-siber biasa diwujudkan melalui happy slapping, yaitu aktivitas merekam atau mengambil gambar seseorang yang berada dalam situasi minoritas atau diserang. Kemudian gambar atau video tersebut didistribusikan kepada orang lain.

Media adalah sarana untuk menyampaikan informasi dan pesan. Media memberikan materimateri pengetahuan untuk dikonstruksi menjadi skema ke dalam pikiran manusia. Adapun eksposur tayangan media adalah aktivitas yang menyebabkan seseorang rentan terhadap efek tayangan media, seperti melihat, mendengar, atau mendengan dan melihat sekaligus. Menurut Milla (2006) meski media berpengaruh pada khalayak, namun jenis media audiovisual lebih patut diperhitungkan. Kekuatan pengaruh media audiovisual disebabkan media jenis ini tidak hanya mengoptimalkan pesan melalui pendengaran, melainkan juga penglihatan dan gerakan sekaligus, dimana pesan bergerak memiliki daya tarik lebih dibandingkan pesan statis.

Remaja mengkonsumsi media rata-rata lebih dari tujuh jam per hari (Strasburger, Jordan, \& Donnerstein, 2010). Konten antisosial, seperti penggunakan obat-obatan terlarang, pertengkaran, seks 
bebas, sangat populer di kalangan remaja (Strasburger, Jordan, \& Donnerstein, 2010). Brown \&Witherspoon (2002) menekankan bahaya tayangan antisosial pada empat isu kesehatan dan sosial yang lazim pada saat ini. Keempat isu tersebut adalah kekerasan dan agresi; seks bebas; obesitas, gizi,dan gangguan makan; dan penyalahgunaan alkohol dan obat-obatan terlarang.

Teori belajar menjelaskan bahwa stimulus-stimulus eksternal merupakan determinan pembentuk perilaku. Manusia memiliki fleksibilitas untuk mempelajari berbagai jenis perilaku melalui pengalaman langsung dan observasi. Teori kognitif sosial yang dipelopori oleh Bandura lebih menekankan proses belajar melalui observasi. Inti dari pembelajaran melalui proses observasi adalah modeling. Pembelajaran melalui modeling melibatkan proses kognitif, yaitu perhatian dan representasi (Feist \& Feist, 2008). Representasi sendiri adalah aktivitas tak sadar untuk merepresentasikan secara simbolis suatu informasi dan menyimpannya untuk digunakan pada kondisi yang mendukung. Manusia mempelajari suatu perilaku dari role model yang ada di lingkungan sekitar (seperti, orang tua, guru, tema) dan media. Dibandingkan dengan lingkungan fisik, media menampilkan pilihan role model yang lebih bervariatif dan menarik.

Di lain pihak, menurut general aggression model (GAM) yang dikembangkan oleh Anderson dan Bushman (2002) setiap orang memiliki reaksi yang berbeda terhadap eksposur tayangan antisosial. Hal ini terjadi karena setiap orang memiliki karakteristik yang membedakan satu sama lain. Variabel personal dan situasional berinteraksi untuk meningkatkan perundungan-siber melalui pengaruh kondisi internal seseorang yang direpresentasikan sebagai afeksi agresi (seperti, mood dan emosi), kognisi agresi (seperti, priming dan script), dan rangsangan fisiologis. Meskipun eksposur tayangan antisosial mempengaruhi ketiga variabel kondisi internal, namun tampaknya eksposur tayangan antisosial lebih mempengaruhi kognisi agresi (Anderson \& Dill, 2000). Kondisi internal 
agresi selanjutnya berpengaruh pada proses penilaian dan pengambilan keputusan. Sebagai contoh, jika seseorang (target) telah memikirkan hal agresif dan memperoleh informasi jika sahabatnya telah mencemarkan nama baiknya, secara spontan dia mengirim pesan singkat yang berisi cacian. Namun, jika target berpikir tentang pengorbanan dan kebaikan aktor, informasi yang diperoleh segera dianggap sebagai omong kosong atau dapat dikatakan bahwa agresi tidak terjadi.

Agreeableness adalah salah satu dimensi kepribadian lima faktor (Big Five Personality) dengan ciri ketulusan dalam berbagi, kehalusan perasaan, fokus pada hal-hal positif orang lain (Ramdhani,2012). Di kehidupan sehari-hari seseorang yang agreeable digambarkan sebagai manusia yang berhati malaikat. Variabel agreeableness dipilih sebagai moderator karena beberapa pertimbangan. Pertama, oleh karena seseorang yang agreeable memiliki empati tinggi (Ashton dan Lee, 2001) maka dimungkinkan apabila mereka melihat tayangan antisosial fokusnya justru pada korban bukan pada pelaku. Kedua, pada saat berada dalam situasi yang dapat memicu kemarahan, seseorang yang agreeable berusaha untuk meredam kemarahan dan memiliki alternatif penyelesaian konflik yang lebih konstruktif (Jensen-Campbell dan Graziano, 2001). Ketiga, penelitian terdahulu menemukan bahwa trait agresi dan psikotik mampu memoderasi efek eksposur media (Bushman, 1995; Anderson dan Dill, 2000; Zilmann dan Weaver, 1997; Markey dan Sherer, 2009).

Bukti empiris lain menunjukkan bahwa agresivitas terkait dengan agreeableness rendah dan psikotisme terkait dengan neuroticism tinggi serta agreeableness rendah (Sharpe dan Desai, 2001). Jadi apabila seseorang yang psikotik dan agresif cenderung mudah dipengaruhi oleh eksposur tayangan antisosial maka dimungkinkan seseorang yang agreeable juga bereaksi sama. Berdasarkan bukti-bukti yang telah dipaparkan maka penelitian ini berusaha untuk mengonfirmasi bahwa agreeableness merupakan moderator hubungan eksposur tayangan antisosial dan perundungan-siber. 


\section{METODE PENELITIAN}

Penelitian ini dilaksanakan di tiga Sekolah Menengah Pertama (SMP) yang ada di Kota Malang. SMP di bagi menjadi dua ketegori, yaitu SMP negeri dan dan SMP swasta. Secara proporsional, diperoleh satu SMP negeri (SMPN 26) dan dua SMP swasta (SMP Muhammadiyah 1 dan SMP Taman Siswa). Teknik pengambilan sampel yang digunakan adalah purposive sampling. Kriteria sampel yang ditetapkan dalam penelitian ini adalah sampel memiliki ponsel atau laptop/komputer. Dari 314 subjek yang telah memenuhi kriteria, selanjutnya dilakukan uji multivariat outlier dan diperoleh 293 sampel.

Menurut Cousineau dan Chartier (2010) multivariat outlier dapat mempengaruhi hasil analisis regresi berganda. Metode yang digunakan untuk outliers creening adalah studentized deleted residual, cook's distance, DFFITS, dan DFBETAS. Data penelitian dari sampel yang memiliki studentized deleted residual $>3,322$, cook's distance $>0,013$, DFFITS $>0,159$, atau DFBETAS $>2$ dikeluarkan. Outlier screening metode studentized deleted residual menemukan empat outlier, cook's distance menemukan 15 outlier, dan DFFITS menemukan 18 outlier. Jumlah dan persentase terkait karakteristik subjek disajikan pada Tabel 1.

Tabel 1. Deskripsi Subjek Penelitian 


\begin{tabular}{lll}
\hline Karakteristik Subjek & $\begin{array}{l}\text { Jumlah } \\
\text { (subjek) }\end{array}$ & $\begin{array}{l}\text { Persentase } \\
(\%)\end{array}$ \\
\hline Jenis Kelamin & & \\
Laki-laki & 149 & 50,85 \\
Perempuan & 144 & 49,15 \\
$\quad$ Jenjang Kelas & & \\
Tujuh (VII) & 149 & 50,85 \\
Delapan (VIII) & 144 & 49,15 \\
$\quad$ Usia & 13 & \\
12 tahun & 128 & 4,44 \\
13 tahun & 122 & 43,69 \\
14 tahun & 29 & 41,64 \\
15 tahun & 1 & 9,70 \\
16 tahun & & 0,34 \\
\hline
\end{tabular}

Instrument penelitian ini adalah The Cyberbullying Questionnaire (CBQ; Calvete et al., 2010) untuk mengukur berbagai kategori perundungan-siber. Terdapat tujuh ketegori perundungan-siber di dalam CBQ, yaitu flamming, outing, denigration, impersonation, happy slapping, exclusion, dan harassement. Hasil uji pilot menghasilkan koefisien Cronbach's $\alpha$ sebesar 0,63. Panayides (2013) menyatakan bahwa suatu skala dikatakan tidak handal apabila memiliki koefisien Cronbach's $\alpha$ di bawah 0,7. Oleh karena itu skala ini harus diujikan kembali. Koefisien Cronbach's $\alpha$ pada uji pilot kedua sudah memenuhi standar yaitu 0,72. Eksposur tayangan antisosial diukur dengan Contentbased Media Exposure Scale (C-ME; Den Hamer, Konijin, \& Keijer, 2013). C-ME terdiri dari 14 item pertanyaan yang menggambarkan tayangan antisosial, prososial, dan netral. Hasil uji pilot menunjukkan koefisien Cronbach's $\alpha$ sebesar 0,82. Agreeableness diukur dengan Big Five Inventori (BFI; John \& Srivastava, 1999) yang telah diadaptasi oleh Ramdhani (2012). Dimensi agreeableness terdiri dari enam komponen, yaitu trust (pemaaf), keterusterangan (tidak menuntut), altruisme (hangat), kepatuhan (tidak keras kepala), kesederhanaan (tidak menunjukkan diri/pamer), dan lembut (simpatis). Uji pilot hanya menunjukkan nilai Cronbach's $\alpha$ sebesar 0,56 sehingga dilakukan uji pilot 
kedua seperti skala perundungan-siber. Koefisien Cronbach's $\alpha$ pada pilot studi kedua sebesar 0,70. Hipotesis di dalam penelitian ini dianalisis dengan menggunakan PROCESS Macro yang dikembangkan oleh Hayes pada tahun 2013. PROCESS Macro menggunakan regresi logistik atau ordinary least square (OLS) berbasis kerangka path analytic untuk menyelidiki dan memvisualisasikan kondisi interaksidalam model moderasi.

\section{HASIL PENELITIAN}

Deskripsi variabel yang disajikan pada Tabel 2 memperlihatkan rentangan, rata-rata $(M)$, dan standar deviasi $(S D)$ variabel perundungan-siber, eksposur tayangan antisosial, dan agreeableness. Berdasarkan perbandingan antara rata-rata skor subjek dan rentangan skor variabel diketahui bahwa kecenderungan perundungan-siber pada remaja berada dalam kategori rendah $(M=14,97 ; S D=$ $3,07)$

pada rentangan $=12-60$. Kecenderungan eksposur tayangan antisosial berada dalam kategori sedang $(M=23,32 ; S D=6,35)$ pada rentangan $=11-55$. Agreeableness berada dalam kategori tinggi $(M=$ $31,20 ; S D=3,73)$ pada rentangan $=9-45$.

Tabel 2. Deskripsi Variabel Penelitian

\begin{tabular}{lccc}
\hline & Rentangan & $M$ & $S D$ \\
\hline Perundungan-siber & $12-60$ & 14,97 & 3,07 \\
$\begin{array}{l}\text { Eksposur tayangan } \\
\text { antisosial }\end{array}$ & $11-55$ & 23,32 & 6,35 \\
Agreeableness & $9-45$ & 31,20 & 3,73 \\
\hline
\end{tabular}

Untuk menguji korelasi antar variabel digunakan metode product moment pearson dengan $p<0,05$ sebagai kriteria signifikansi. Tabel 3 memperlihatkan hasil analisis berupa koefisien korelasi pearson beserta taraf signifikansinya. Interpretasi dari hasil tersebut adalah perundungan-siber secara 
signifikan berkorelasi dengan eksposur tayangan antisosial $(r=0,31 ; p=0,00)$ dan agreeableness $(r$ $=-0,15 ; p=0,01)$. Sementara eksposur tayangan antisosial dan agreeableness tidak berkorelasi $(r=$ $0,03 ; p=0,56)$.

Tabel 3. Korelasi Antar Variabel

\begin{tabular}{lccc}
\hline & $\begin{array}{c}\text { Perundungan- } \\
\text { siber }\end{array}$ & Eksposur & Agreeableness \\
\hline Perundungan-siber & 1 & $0,313^{* * *}$ & $-0,149^{*}$ \\
Eksposur & & 1 & 0,034 \\
Agreeableness & & & 1 \\
\hline Catatan: $p<0,05 ; " p<0,001$. & & &
\end{tabular}

Tabel 3 memperlihatkan hasil analisis untuk sumbangan efektif variabel eksposur tayangan antisosial, agreeableness dan interaksi variabel eksposur dan agreeableness (eksposur x agreeableness) terhadap variabel perundungan-siber. Hasil analisis memutuskan adanya pengaruh signifikan eksposur tayangan antisosial terhadap perundungan-siber $(F=31,68 ; p=0,00)$, sumbangan efektif eksposur tayangan antisosial terhadap perundungan-siber sebesar $10 \%(\mathrm{R} 2=0,10)$. Pada agreeableness terhadap perundungan-siber diputuskan ada pengaruh signifikan $(F=6,56 ; p=0,01)$, sumbangan efektif agreeableness terhadap perundungan-siber sebesar $2 \%(\mathrm{R} 2=0,02)$. Pada agreeablenesss sebagai moderator hubungan eksposur tayangan antisosial dan perundungan-siber ditemukan pengaruh signifikan $(F=5,13 ; \mathrm{p}=0,02)$, dengan sumbangan efektif sebesar $2 \%(\mathrm{R} 2=0,02)$. Dengan demikian, ketiga variabel secara simultan mampu menjelaskan varians perundungan-siber sebesar $14 \%(F=16,06 ; p=0,00 ; R 2=0,14)$, sisanya sebesar $86 \%$ dijelaskan oleh variabel lain.

Analisis PROCESS Macro mengungkapkan bahwa eksposur tayangan antisosial secara signifikan berhubungan positif dengan perundungan-siber $(\beta=0,141 ; t=6,383 ; p=0,000)$, bahwa semakin tinggi eksposur tayangan antisosial maka semakin tinggi perundungan-siber. Temuan lainnya adalah adanya hubungan negatif yang signifikan pada agreeableness dan perundungan-siber, $(\beta=$ - 
$0,103 ; t=-3,283 ; p=0,001)$, maknanya semakin tinggi agreeableness maka semakin tinggi perundungan-siber. Konsisten dengan hipotesis, agreeableness merupakan moderator pada hubungan eksposur tayangan antisosial dan perundungan-siber, yang diketahui dari adanya hubungan negatif dan signifikan pada variabel eksposur $X$ perundungan-siber dan agreeableness $(\beta=-0,155 ; \mathrm{t}=-2,785$; $\mathrm{p}=0,006)$. Secara khusus, hasil analisis menunjukkan adanya perbedaan kekuatan hubungan eksposur tayangan antisosial terhadap perundungan-siber di setiap level agreeableness. Hasil analisis moderasi disajikan pada Tabel 4.

Tabel 4. Sumbangan dan Hubungan Variabel

\begin{tabular}{lcccc}
\hline \multicolumn{1}{c}{ Variabel } & $R^{2}$ & $F$ & $\mathrm{~B}$ & $T$ \\
\hline Eksposur Tayangan & 0,098 & $31,675^{* * *}$ & 0,1407 & $6,3827^{* * *}$ \\
Antisosial & & & & \\
Agreeableness & 0,022 & $6,562^{*}$ & $-0,1034$ & $-3,2826^{* *}$ \\
Eksposur x & 0,017 & $5,129^{*}$ & $-0,1552$ & $-2,7846^{* *}$ \\
Agreeableness & & & & \\
\hline Catatan: ${ }^{*} p<0,05^{* *} p<0,01 ;^{* * *} p<0,001$. & & & &
\end{tabular}

Analisis efek sederhana dilakukan untuk mengetahui kekuatan pengaruh eksposur tayangan antisosial terhadap perundungan-siber di level agreeableness rendah (1 SD dibawah rerata skor agreeableness), sedang (rerata skor agreeableness), dan tinggi (1 SD di atas rerata skor agreeableness). Gambar 1 memperlihatkan bahwa eksposur tayangan antisosial yang tinggi mampu meningkatkan rerata perundungan-siber apabila level agreeableness semakin rendah. Sebaliknya meski eksposur tayangan antisosial tinggi, rerata perundungan-siber justru menurun apabila level agreeableness semakin tinggi. Sehingga dapat disimpulkan bahwa hubungan eksposur tayangan antisosial terhadap perundungan-siber semakin kuat apabila remaja memiliki level agreeableness rendah dibanding dengan remaja dengan level agreeableness tinggi. 


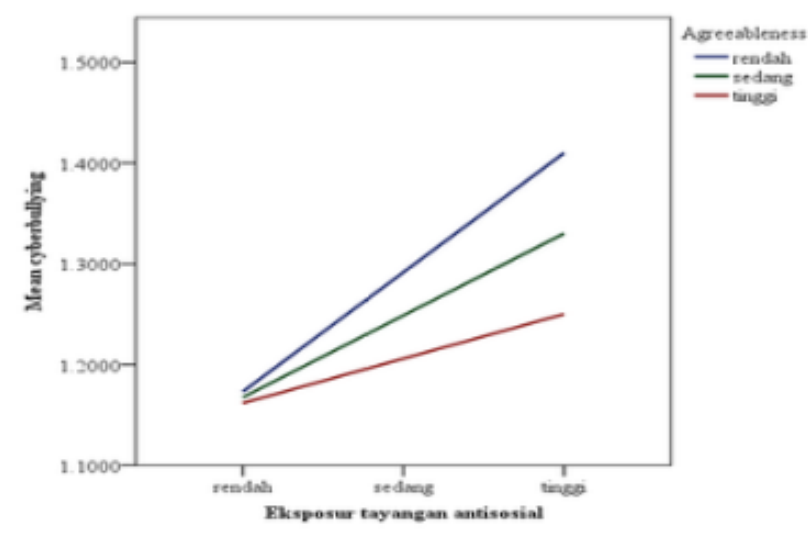

Gambar 1. Kondisi interaksi eksposur tayangan antisosial dan agreeableness terhadap perundungan-siber (cyberbullying)

\section{DISKUSI}

Penelitian ini dirancang untuk mengetahui pengaruh agreeableness terhadap hubungan eksposur tayangan antisosial dan perundungan-siber. Konsisten dengan hipotesis, hasil analisis memutuskan agreeableness berpengaruh pada hubungan eksposur tayangan antisosial dan perundungan-siber. Semakin rendah level agreeableness maka semakin lemah besaran efek eksposur tayangan antisosial terhadap perundungan-siber. Hasil penelitian ini sejalan dengan Meier, Robinson, dan Wilkowski (2006), bahwa agreeableness adalah moderator eksposur tayangan antisosial. Pada kondisi normal pikiran agresi secara otomatis diaktifkan dan pada saat menyaksikan tayangan antisosial dan menyebabkan seseorang untuk bertindak agresi. Sebagai contoh, apabila seseorang memainkan grand theft auto (video game dengan konten antisosial) maka pikiran agresi akan diaktifkan dan pada kondisi tertentu, seperti ketika ada seseorang yang tidak sengaja menabraknya, reaksi yang timbul adalah umpatan. Namun, orang-orang yang agreeable adalah mereka yang hangat dan ramah, dan tampaknya dapat meredakan situasi tegang dengan memunculkan ide-ide prososial. Oleh karena itu menurut Meier, Robinson, dan Wilkowski (2006) pada mereka yang agreeable akan meregulasi pikiran agresi, 
sehingga meminimalkan pengaruh eksposur tayangan antisosial pada perilaku, sedangkan individu non-agreeable tidak.

Hasil studi ini juga memutuskan bahwa agreeableness tidak hanya berfungsi sebagai moderator dari hubungan eksposur tayangan antisosial dan perundungan-siber namun juga berfungsi sebagai variabel bebas dari perundungan-siber. Antara agreeableness dan perundungan-siber memiliki hubungan yang negatif. Temuan ini sejalan dengan temuan dari Kokkinos, Baltzidis, dan Xynogala (2016), bahwa agreeableness memiliki hubungan negatif dengan perundungan di dalam facebook. Bahkan dibandingkan dengan dimensi lima faktor lainnya, hanya agreeableness yang secara signifikan berhubungan dengan perundungan di dalam facebook. Bukti empiris menunjukkan, aspekaspek yang ada di dalam agreeableness menyebabkan seseorang yang agreeable lebih termotivasi untuk menjaga hubungan harmonis dengan orang lain dan melakukan tindakan prososial (Graziano, Jensen-Campbell, \& Hair, 1996; Caprara, Alessandri, Di Giunta, Panerai, \& Eisenberg, 2010). Sistem motif ini membimbing seseorang agreeable untuk menghindari situasi, pandangan, dan tindakan yang dapat memicu konflik dan merugikan orang lain.

Untuk penelitain selanjutnya diharapkan dapat mengeksplorasi faktor-faktor lain yang berpotensi menjadi moderator dari efek eksposur tayangan antisosial. Menurut Valkenburg dan Peter (2013) selain kepribadian, perkembangan dan sosial juga mampu mempengaruhi efek dari eksposur tayangan antisosal. Faktor perkembangan terkait dengan perkembangan emosi dan kognitif, yang mana anak-anak lebih rentan terhadap efek tayangan media dibanding orang dewasa. Sesuai dengan kemampuan kognisinya, anak-anak belum dapat berfikir secara abstrak. Bandura telah melakukan eksperimen terkait efek tayangan kekerasan pada anak-anak (eksperimen bobo doll). Dari eksperimen tersebut terlihat bahwa setelah melihat beberapa adegan kekerasan anak-anak langsung 
mengimitasinya. Pengaruh sosial menurut Valkenburg dan Peter (2013) terjadi dalam dua cara yaitu ketika orang tua, saudara, sekolah, atau lembaga membatasi atau mengatur penggunaan media; atau lebih melalui norma-norma yang berlaku dalam keluarga, kelompok sebaya, atau (sub) budaya.

Beberapa keterbatasan harus dipertimbangkan ketika menafsirkan hasil penelitian ini. Pertama, sampel diambil dari zona geografis yang terbatas dan hanya pada siswa SMP kelas tujuh dan delapan di tiga lokasi. Sehingga untuk penelitian di masa depan dapat menggunakan sampel penelitian pada populasi yang lebih luas dan berada pada jenjang pendidikan lainnya. Kedua, di dalam penelitian ini menggunakan satu metode pengambilan data, yaitu self report. Penelitian di masa depan dapat mengkombinasikan dua metode pengambilan data baik self report maupun pengambilan data dari pihak terdekat sampel untuk memperkaya data tentang sampel penelitian.

\section{KESIMPULAN DAN SARAN}

Berdasarkan hasil penelitian ini disimpulkan bahwa agreeableness adalah variabel moderator pada hubungan eksposur tayangan antisosial dan perundungan-siber. Hubungan eksposur tayangan antisosial dan perundungan-siber lebih kuat apabila remaja memiliki agreaableness rendah. Sebaliknya hubungan eksposur tayangan antisosial dan perundungan-siber semaking lemah apabila remaja memiliki agreeableness tinggi.

Hasil penelitian ini diharapkan dapat memberikan sumbangan bagi ilmu pengetahuan di bidang psikologi sosial, khususnya sebagai bahan referensi mengenai pengaruh agreeableness untuk memoderasi eksposur tayangan antisosial dan perundungan-siber. Hasil penelitian ini juga diharapkan dapat menjadi bahan masukan bagi para praktisi dan profesional bahwa tidak semua remaja memperoleh dampak eksposur tayangan antisosal. Pada individu dengan level agreeableness rendah 
lebih rentan terhadap efek eksposur tayangan antisosial dibandingkan dengan individu dengan level agreeableness tinggi. Walaupun agreeableness merupakan ciri yang menetap di diri individu, namun dengan mengajarkan sejak dini mengenai altruisme dan kelembutan hati mungkin dapat menghambat efek dari eksposur tayangan antisosial.

\section{DAFTAR PUSTAKA}

Anderson, C. A., \& Bushman, B. J. (2002). Human aggression. Annual Review of Psychology, 53, 2751.

Anderson, C. A., \& Dill, K. E. (2000). Video games and aggressive thoughts, feelings, and behavior in the laboratory and in life. Journal of Personality and Social Psychology, 78 (4), 772-790.

Ashton, M. C., \& Lee, K. (2001). A theoretical basis for the major dimensions of personality. European Journal of Personality, 15 (5), 327-353.

Brown, J. D., \& Witherspoon, E. M. (2002). The mass media and American adolescents' health. Journal of Adolescent Health, 31, 153-170.

Bushman, B. J. (1995). Moderating role of trait aggressiveness in the effects of violent media on aggression. Journal of Personality and Social Psychology, 69 (5), 950-960.

Calvete, E., Orue, I., Estevez, A., Villardon, L., \& Padilla, P. (2010). Cyberbullying in adolescents: Modalities and aggressors' profile. Computers in Human Behavior, 26 (5), 1128-1135.

Caprara, G. V., Alessandri, A., Di Giunta, L., Panerai, L., \& Eisenberg, N. (2010). The contribution of agreeableness and self-efficacy beliefs to prosociality. European Journal of Personality, 24 (1), 36-55.

Cousineau, D., \& Chartier, S. (2010). Outliers detection and treatment: A review. International Journal of Psychological Research, 3 (1), 58-67.

Den Hamer, A. H., \& Konijn, E. A. (2015). Adolescents' media exposure may increase their cyberbullying behavior: a longitudinal study. Journal of Adolescent Health, 56 (2), 203-208.

Den Hamer, A., Konijin, E. A., \& Keijer, M. G. (2013). Cyberbullying behavior and adolescents' use of media with antisocial content: A cyclic process model. Cyberpsychology Behavior Social Network, 17 (2), 74-81.

Dordolo, N. (2014). The role of power imbalance in cyberbullying. The Undergraduate Journal of Psychology, 3, 35-41.

Feist, Jess., \& Feist. G. J. (2008). Theories of Personality. Yogyakarta: Pustaka Belajar. Ferguson, C. J., \& Wang, J. C. K. (2019). Aggressive video games are not a risk factor for future aggression: A longitudinal study. $J$ Youth Adolesc, 48 (8), 1439-1451. Graziano, W. G., Jensen-Campbell, L. A., \& Hair, E. C. (1996). Perceiving interpersonal conflict and reacting to it: The case for agreeableness. Journal of Personality and Social Psychology, 70 (4), 820-835.

Jensen-Campbell, L. A., \& Graziano, W. G. (2001). Agreeableness as a moderator of interpersonal conflict. Journal of Personality, 69 (2), 323-362. 
John, O. P., \& Srivastava, S. (1999). The big five trait taxonomy: History, measurement, and theoretical perspectives. In L. A. Pervin \& O. P. John (Eds.), Handbook of personality: Theory and research. New York: Guilford Press.

Kokkinos, C. M., Baltzidis, E., \& Xynogala, D. (2016). Prevalence and personality correlates of Facebook bullying among university undergraduates. Computers in Human Behavior, 55, 840850.

Kowalski, R. M., Giumetti, G. W., Schroeder, A. N., \& Lattanner, M. R. (2014). Bullying in the digital age: A critical review and meta-analysis of cyberbullying research among youth. Psychology Bullying, 140 (4), 1073-1137.

Mawardah, M., \& Adiyanti, M. G. (2014). Regulasi emosi dan kelompok teman sebaya pelaku

Markey, P. M., \& Scherer, K. (2009). An examination of psychoticism and motion capture controls as moderators of the effects of violent videogames. Computers in Human Behavior, 25 (2), $407-$ cyberbullying. Jurnal Psikologi, 41 (1), 60-73.

Meier, B. P., Robinson, M. D., \& Wilkowski, B. M. (2006). Turning the other cheek: Agreeableness and the regulation of aggression-related primes. Psychological Science, 17, (2) 136-142.

Ramdhani, N. (2012). Adaptasi bahasa dan budaya inventori big five. Jurnal Psikologi, 39 (2), 189 207.

Smith, P. K. (2015). The nature of cyberbullying and what we can do about it. Journal of Research in Special Educational Needs, 15 (3), 176-184.

Strasburger, V. C., Jordan, A. B., \& Donnerstein, E. (2010). Health effects of media on children and adolescents. Pediatrics, 125, 756-767.

Tokunaga, R. S. (2010). Following you home from school: A critical review and synthesis of research in cyberbullying victimization. Computers in Human Behavior, 26 (3), 277-287.

Valkenburg, P. M., \& Peter, J. (2013). The differential susceptibility to media effects model. Journal of Communication, 63 (2), 221-243.

https://wearesocial.com/blog/2020/01/digital-2020-3-8-billion-people-use-social-media Zilmann, D., $\&$ Weaver, J. B. (1997). Psychoticism in the effect of prolonged exposure to gratuitous media violence on the acceptance of violence as a preferred means of conflict resolution. Personality and Individual Differences, 22 (5), 613-62

Milla, M, N. (2006). Pengaruh terpaan kekerasan media audio-visual pada kognisi agresif dan afeksi agresif studi meta-analisis. Jurnal Psikologi, 33, 1-16.

Nansel, T. R., Overpeck, M. D., Haynie, D. L., Ruan, W. J., \& Scheidt, P. C. (2003). Relationships between bullying and violence among U.S. youth. Archives of Pediatric Adolescent Medicine, 157 (4), 348-353.

Panayides, P. (2013). Coefficient alpha: Interpret with caution. Europe's Journal of Psychology, 9 (4), 687-696.

Willard, N. (2007). Educator's guide to cyberbullying and cyberthreats. Eugene, OR: Center for Safe and Responsible Internet Use. Diakses dari http://www.cyberbully.org/docs/cbcteducator.pdf

Zilmann, D., \& Weaver, J. B. (1997). Psychoticism in the effect of prolonged exposure to gratuitous media violence on the acceptance of violence as a preferred means of conflict resolution. Personality and Individual Differences, 22 (5), 613-62 
PSYCHE: JURNAL PSIKOLOGI UNIVERSITAS MUHAMMADIYAH LAMPUNG ISSN (electronic) 2655-6936

Vol.2 No. 2, Agustus 2020 